\title{
強度増進の温度依存性に及ぼすセメント鉱物組成の影響 EFFECTS OF THE MINERAL COMPOSITION OF CEMENT ON THE TEMPERATURE DEPENDENCY OF STRENGTH DEVELOPMENT
}

\author{
谷口 円*, 桂修**, 佐川孝広***, 濱幸雄**** \\ Madoka TANIGUCHI, Osamu KATSURA, Takahiro SAGAWA \\ and Yukio HAMA
}

\begin{abstract}
In recent years, use of low heat Portland cement is promoted. However, there was no general method to predict the strength development of the concrete using cement which has wide range of mineral composition. In low heat Portland cement, it was pointed out that application of "Maturity method" was difficult. We considered application of the equivalent age to predict the strength development of concrete using various type of cement. Then, we examined the strength development of mortar using cement has wide range of mineral composition under different curing temperature. As a result, the temperature dependency of strength development of various cements was explained by the equivalent age. The values of the apparent activation energy of cement were dependent on its mineral composition.
\end{abstract}

Keywords: Strength Development, Cement, Mineral Composition, Equivalent age, Apparent Activation Energy 強度増進性状，セメント，鉱物組成，等価材齢，見かけの活性化エネルギー

\section{1. はじめに}

コンクリートの圧縮強度はセメントの水和反応に依存し，温度と 時間の影響を大きく受ける。特に寒冷期のコンクリート工事では, 低温の影響により強度増進が遅れるため，工事を支障なく行うため には計画した材齢で所要の強度を得るための対応が重要となる。日 本建築学会「寒中コンクリート施工指針・同解説」1)では温度・時 間関数である積算温度を用いた計画・管理方法が示され実務に用い られ, 1998 年からは圧縮強度増進を予測する強度増進標準曲線が示 されている.

積算温度で強度值を整理する方法は 1950 年代に示され, 我が国に 導入され実務に適用寸る方式が作られたのは 1959 年であった ${ }^{2)}$.た だし，この基準温度を一定とした積算温度の適用は経験則に基づく 利用であり，普通ポルトランドセメントに対応したものであった。 その後, ビーライトを多く含む低熱ポルトランドセメントが開発さ れたが，これを用いたコンクリートでは基準温度を $-10^{\circ} \mathrm{C}$ とた従 来の積算温度方式の適用が困難であること ${ }^{344}$ や, 低熱セメントでも メーカーにより強度増進性状が異なること ${ }^{5)}$ が報告されている．筆 者ら 6)も普通, 中庸熱, 低熱ポルトランドセメントを用いたコンク
リートで，養生温度を変えた圧縮強度増進性状の実験を行い，低熱 ポルトランドセメントを使用したコンクリートには基準温度を-10 ${ }^{\circ} \mathrm{C}$ とした積算温度が適用できないことを確認した。使用するコンク リート毎に最適な基準温度を試験結果から定める方法も示される 7 が，数水準の温度条件での試験が必要であり実用的でない。

一方，等価材齢(Equivalent age)も温度時間関数として知られてい る.セメントの水和反応の温度依存性はアレニウス則に従うとして, 様々な温度条件での材齢を基準温度の材齢に換算するものであるが, 算定にはセメントごとに活性化エネルギーが必要となる. Carino ら 6)の研究を受けたASTM10747)には等価材齢の算定に用いる見かけの 活性化エネルギーをモルタル実験から求める方法が示される.また, Schindler ${ }^{8}$ は見かけの活性化エネルギーの值をアルミネート, フェラ イト，ブレーン比表面積の関数とした実験式を示している．筆者ら は算定に用いた各セメントの見かけの活性化エネルギーの值が鉱物 組成に依存する傾向を明らかにしている ${ }^{6}$.

セメントは, エーライト (けい酸三カルシウム, 以下 $\mathrm{C}_{3} \mathrm{~S}$ ), ビー ライト (けい酸二カルシウム, 以下 $\mathrm{C}_{2} \mathrm{~S}$ ), アルミネート（以下 $\mathrm{C}_{3} \mathrm{~A}$ ), フェライト (以下 $\left.\mathrm{C}_{4} \mathrm{AF}\right)$ の主要 4 鉱物からなり，鉱物組成とブ
${ }^{*}$ 北海道立総合研究機構北方建築総合研究所環境科学部 研究主任·工修 (室蘭工業大学大学院工学研究科建設工学専攻 博士後期課程)

***北海道立総合研究機構北方建築総合研究所居住科学部 研究主幹. 博士 ( 工学)

*** 日鐵セメント侏技術部研究所 副主幹研究員・博士 (工学)

**** 室蘭工業大学大学院工学研究科 $<ら し$ 環境系領域 教授・博士 (工学)
Researcher, Environmental Engineering Division, Hokkaido Research Organization Northern Regional Building Research Institute, M. Eng.

(Graduate Student, Graduate School of Eng., Muroran Institute of Technology)

Senior Research Manager, Residential Planning Division, Hokkaido Research Organization Northern Regional Building Research Institute, Dr. Eng.

Research Manager, Technical Development Lab., Nittetsu Cement Co., Ltd., Dr. Eng. Prof., College of Environmental Technology, Muroran Institute of Technology, Dr. Eng. 
表 1 セメントの物性值と鉱物組成

\begin{tabular}{|c|c|c|c|c|c|c|c|c|}
\hline \multicolumn{2}{|c|}{ セメント種類 } & \multirow{2}{*}{$\begin{array}{c}\text { 密度 } \\
\left(\mathrm{g} / \mathrm{cm}^{3}\right)\end{array}$} & \multirow{2}{*}{$\begin{array}{l}\text { ブレーン } \\
\text { 比表面積 } \\
\left(\mathrm{cm}^{2} / \mathrm{g}\right)\end{array}$} & \multicolumn{5}{|c|}{ 鉱物組成(リートベルト) $(\%)$} \\
\hline & 記号 & & & $\mathrm{C}_{3} \mathrm{~S}$ & $\mathrm{C}_{2} \mathrm{~S}$ & $\mathrm{C}_{3} \mathrm{~A}$ & $\mathrm{C}_{4} \mathrm{AF}$ & Total \\
\hline 早強 & $\mathrm{H}$ & 3.12 & 4780 & 76 & 3 & 7 & 8 & 94 \\
\hline \multirow{2}{*}{ 普通 } & N1 & 3.17 & 3450 & 68 & 13 & 4 & 11 & 96 \\
\hline & $\mathrm{N} 2$ & 3.16 & 3460 & 68 & 13 & 6 & 10 & 97 \\
\hline \multirow{4}{*}{ 中庸熱 } & M1 & 3.23 & 3030 & 54 & 28 & 2 & 12 & 96 \\
\hline & M2 & 3.21 & 3710 & 40 & 43 & 5 & 8 & 96 \\
\hline & M3 & 3.24 & 3100 & 43 & 41 & 1 & 13 & 98 \\
\hline & M4 & 3.23 & 3080 & 55 & 26 & 2 & 14 & 97 \\
\hline \multirow{4}{*}{ 低熱 } & $\overline{\mathrm{L} 1}$ & 3.23 & 3420 & 27 & 58 & 2 & 8 & 95 \\
\hline & $\mathrm{L} 2$ & 3.24 & 3590 & 25 & 58 & 2 & 9 & 94 \\
\hline & L3 & 3.22 & 3500 & 32 & 52 & 3 & 9 & 96 \\
\hline & L4 & 3.24 & 3330 & 32 & 52 & 3 & 10 & 97 \\
\hline
\end{tabular}

レーン比表面積がセメント種類により異なることが広く知られてい

る.「JIS R5210:2009 ポルトランドセメント」では, 中庸熱ポルトラ ンドセメントでは $\mathrm{C}_{3} \mathrm{~S}$ 量が $50 \%$ 以下, 低熱ポルトランドセメントで は $\mathrm{C}_{2} \mathrm{~S}$ 量が $40 \%$ 以上と, それぞれ上限值および下限值のみが規定さ れ, 同じ種類のセメントでも鉱物組成に幅のあることが考えられる. 混合セメントを除くと, これまでの多くの実験研究により示されて きたセメント種類によるコンクリートの強度増進性状等の違いは, 主要鉱物の組成および反応に依存したものと推察することもできる.

以上をふまえ, 本研究では, 使用するセメント種類によるコンク リート強度増進の温度依存性の相違を, 鉱物組成を指標としてとら え直し, 強度増進の温度・時間依存性を記述寸る手法を提案するこ とを目的とした検討を行った。はじめにセメントペーストの実験を 行い, 強度増進を担うセメント鉱物 $\left(\mathrm{C}_{3} \mathrm{~S}, \mathrm{C}_{2} \mathrm{~S}\right)$ の反応の温度依存 性を評価した。次にモルタルを用い, 国内の 3 メーカーの広範囲な 鉱物組成を持つポルトランドセメント 11 種を使用し, 強度増進の温 度依存性を評価し，鉱物組成の影響を検討した。

\section{2. 使用したセメント}

セメントは, ポルトランドセメントとし, 早強ポルトランドセメ ント (以下早強セメント) 1 種類 $(\mathrm{H})$, 普通ポルトランドセメント (以 下普通セメント） 2 種類（N1, N2), 中庸熱ポルトランドセメント (以下中庸熱セメント) 4 種類(M1 M4), 低熱ポルトランドセメン ト（以下低熱セメント） 4 種類(L1 L4)の合計 11 種類を用意した. 表 1 に各セメントのブレーン比表面積, 密度, X 線回折リートベル 卜法により定量された主要 4 鉱物の割合を示寸。ペースト実験では N2, M3, L4 の 3 種類, モルタル実験では 11 種類すべてを使用し た.

\section{3. セメントペーストによる検討}

\section{1 実験概要}

セメント鉱物（ $\left.\mathrm{C}_{3} \mathrm{~S} ， \mathrm{C}_{2} \mathrm{~S}\right)$ の反応の温度時間依存性を評価した。 セメントの水和解析は近年研究が盛んである ${ }^{9110) 111212} X$ 線回折リー トベルト解析で行った。

\section{1 .1 水和試料の作製と調製}

ペーストの水セメント比は 50\%とし, 混練は JISR5201 に準じて 行った。混練後 $4 \times 4 \times 16 \mathrm{~cm}$ の型枠に成型し, 普通セメントでは約 半日, 中庸熱，低熱セメントで約 1 日 $20^{\circ} \mathrm{C}$ 封緘養生を行った。脱型 後, 厚さ約 $3 \mathrm{~mm}$ に切断し, 飽和水酸化カルシウム溶液とともにチ ヤック付きビニル袋に密封し, 所定の温度に調整された水槽で, 所
表 2 実験計画

\begin{tabular}{c|c|c}
\hline $\begin{array}{c}\text { 水セメント比 } \\
(\%)\end{array}$ & $\begin{array}{c}\text { 養生温度 } \\
\left({ }^{\circ} \mathrm{C}\right)\end{array}$ & $\begin{array}{c}\text { 材齢 } \\
(\text { 日 })\end{array}$ \\
\hline \multirow{3}{*}{50} & 20 & $1,3,7,28,56,91,(182)$ \\
\cline { 2 - 3 } & 5 & $7,28,56,91,(182)$ \\
\cline { 2 - 3 } & 50 & $3,7,14,28,(91)$ \\
\hline
\end{tabular}

定の材齢まで養生した．表 2 に実験計画を示す．養生後の試料は， アセトンにより水和を停止させ， D 乾燥を行った．乾燥後の試料は 鉄乳鉢で粗粉砕後, ボールミルにて微粉砕した。

\section{1 .2 反応率の測定}

$\mathrm{X}$ 線回折の測定は, 内部標準物質としてコランダムを内割 $10 \%$ 添 加して行った。測定条件は X 線源 $\mathrm{Cu}-\mathrm{K} \alpha$, 管電圧 $40 \mathrm{kV}$, 管電流 $40 \mathrm{~mA}$, 走查範囲 $2 \theta 5 \sim 65^{\circ}$ ，ステップ幅 $0.02^{\circ}$ ，計数時間 2 秒で 行い, 回転試料台，モノクロメーターを使用した。リートベルト解 析は RIETAN-200013)を用いた。解析, 定量の対象鉱物は $\mathrm{C}_{3} \mathrm{~S}, \mathrm{C}_{2} \mathrm{~S}$,

$\mathrm{C}_{3} \mathrm{~A}, \mathrm{C}_{4} \mathrm{AF}$, 水酸化カルシウム,モノサルフェート, カルサイトと しセメント鉱物結晶構造データの初期值は佐川ら 10)の值を用いた.

セメント鉱物の反応率の算出方法は佐川ら 10)の方法にならい, 得 られた定量值を内部標準量と強熱減量にて補正し，未水和セメント 鉱物定量値との比から算出した。

強熱減量の測定は TG-DTA で行った。測定条件は, 昇温速度 $20^{\circ} \mathrm{C}$ /min, $\mathrm{N}_{2}$ フロー $(200 \mathrm{ml} / \mathrm{min})$ 環境下で常温から $1000^{\circ} \mathrm{C}$ の範囲で 行い, 常温 $\sim 1000^{\circ} \mathrm{C}$ 質量減少を強熱減量とした.

\section{2 結果および考察}

$\mathrm{C}_{3} \mathrm{~S}, \mathrm{C}_{2} \mathrm{~S}$ の反応について温度時間関数による温度依存性の評価 を行う.

図 1 に基準温度をー $10^{\circ} \mathrm{C}$ とした積算温度と $\mathrm{C}_{3} \mathrm{~S}$ および $\mathrm{C}_{2} \mathrm{~S}$ の反 応率の関係をセメントごとに示寸.積算温度の算出式をここに示す.

$$
\begin{aligned}
& M=\sum(T+10) \Delta t \\
& \text { ここに, } M: \text { 積算温度 }\left({ }^{\circ} \mathrm{D} ・ \mathrm{D}\right) \\
& T: \text { 期間 } \Delta t \text { のコンクリート温度 (養生温度 }) \text { の } \\
& \quad \text { 平均 }\left({ }^{\circ} \mathrm{C}\right), \\
& \Delta t \text { : 期間 }(\text { 日 })
\end{aligned}
$$

得られた反応率が途中で低下が認められる場合もあり，測定誤差 によるものと考えられるが，全体的な温度依存性の傾向は捉えられ るものと判断した.

$\mathrm{C}_{3} \mathrm{~S}$ では異なる養生温度の反応率を積算温度によりほぼ一義的 に表すことができるが， $\mathrm{C}_{2} \mathrm{~S}$ では表せないことが示されている.

等価材齢は以下の式で示される.

$T_{e}=\left(\frac{k_{T_{c}}}{k_{T_{f f}}}\right) \times \Delta t$

ここに, $T_{e}$ ：等価材齢(日), $k_{T c}$ ：温度 $T_{c}$ での反応速度定数, $k_{T r f}$ : 基準温度 $T_{r f}$ での反応速度定数, $\Delta t:$ 時間間隔

反応速度定数 $\mathrm{k}_{\mathrm{T}}$ は Arrehenius 式による.

$$
\begin{aligned}
& k_{T}=A \exp \left(\frac{-E}{R T}\right) \\
& \text { ここに, } A \text { : 前指数項, }
\end{aligned}
$$



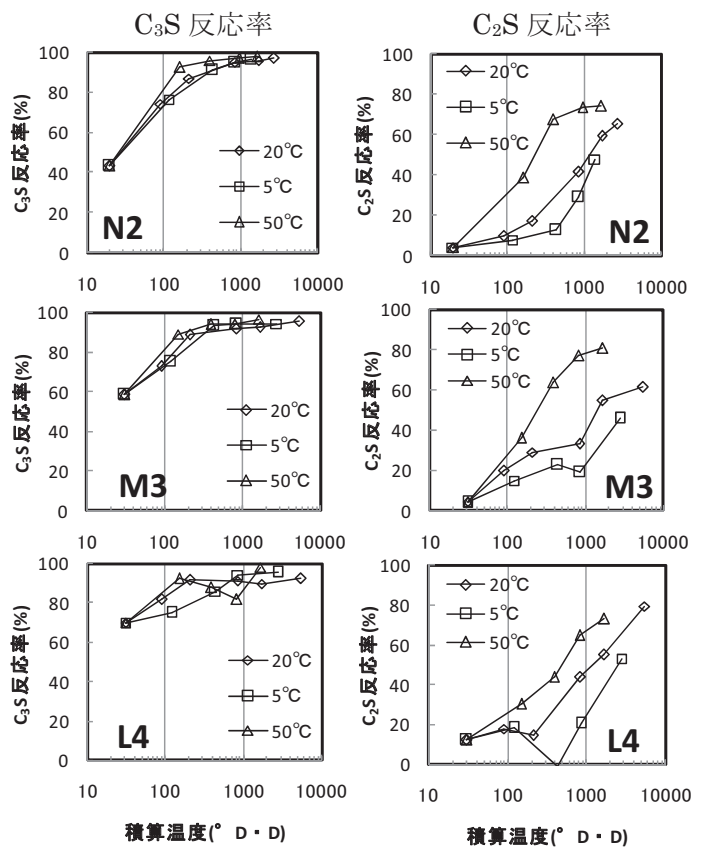

図 1 基準温度 $-10^{\circ} \mathrm{C}$ の積算温度と $\mathrm{C}_{3} \mathrm{~S}, \mathrm{C}_{2} \mathrm{~S}$ 反応率の関係

$$
\begin{aligned}
& E: \text { 見かけの活性化エネルギー }(\mathrm{J} / \mathrm{mol}), \\
& R: \text { 気体定数 }(\mathrm{J} / \mathrm{molK}), \\
& T: \text { 温度 }(\mathrm{K})
\end{aligned}
$$

算定に必要となる見かけの活性化エネルギーの值は, 文献值 14$)$ $\left(\mathrm{C}_{3} \mathrm{~S}: 26.5 \mathrm{~kJ} / \mathrm{mol}, \mathrm{C}_{2} \mathrm{~S}: 60.1 \mathrm{~kJ} / \mathrm{mol}\right)$ を用いた。

図 2 に等価材齢と反応率の関係を示す. 等価材齢を用いると, $\mathrm{C}_{3} \mathrm{~S}$, $\mathrm{C}_{2} \mathrm{~S}$ ともに養生温度の異なる水和の進行をほぼ一義的に表すことが できた.

普通セメントは基準温度を $-10^{\circ} \mathrm{C}$ とた積算温度により強度増 進の温度依存性を表すことができる。しかし, 低熱セメントは基準 温度を $-10^{\circ} \mathrm{C}$ した積算温度が適用できないことが指摘されてい る ${ }^{344) 6)}$ 。このことは， $\mathrm{C}_{2} \mathrm{~S}$ の反応の温度時間依存性が積算温度で表 せないため, $\mathrm{C}_{2} \mathrm{~S}$ 割合の多い低熱セメントの強度増進には積算温度 が適用できないものと考えられる。

$\mathrm{C}_{3} \mathrm{~S} ， \mathrm{C}_{2} \mathrm{~S}$ それぞれの見かけの活性化エネルギーを用いた等価材 齢では $\mathrm{C}_{3} \mathrm{~S}, \mathrm{C}_{2} \mathrm{~S}$ それぞれの反応の温度依存性を表すことができた。 ポルトランドセメントの強度増進は主に $\mathrm{C}_{3} \mathrm{~S}, \mathrm{C}_{2} \mathrm{~S}$ の反応によるこ とから, 適切な見かけの活性化エネルギーの值を得ることで, 等価 材齢によって強度増進の温度時間依存性を表すことができると考え られる。

\section{4. モルタルによる検討}

\section{1 実験概要}

\subsection{1 使用材料と試験体の作製}

使用したセメントは表 1 に示寸 11 種類とした. 調合および試験 体作製は，JISR5201-1997「セメントの物理試験方法 10.強さ試験」 に準じて行った. 試験体数が多いことから, 混練は 45 リットル傾 胴形ミキサーを用いて行った。

\subsection{2 実験方法}

表 3 に実験計画を示す．型枠の脱型は材齢 1 日で行い， $5,20,35$
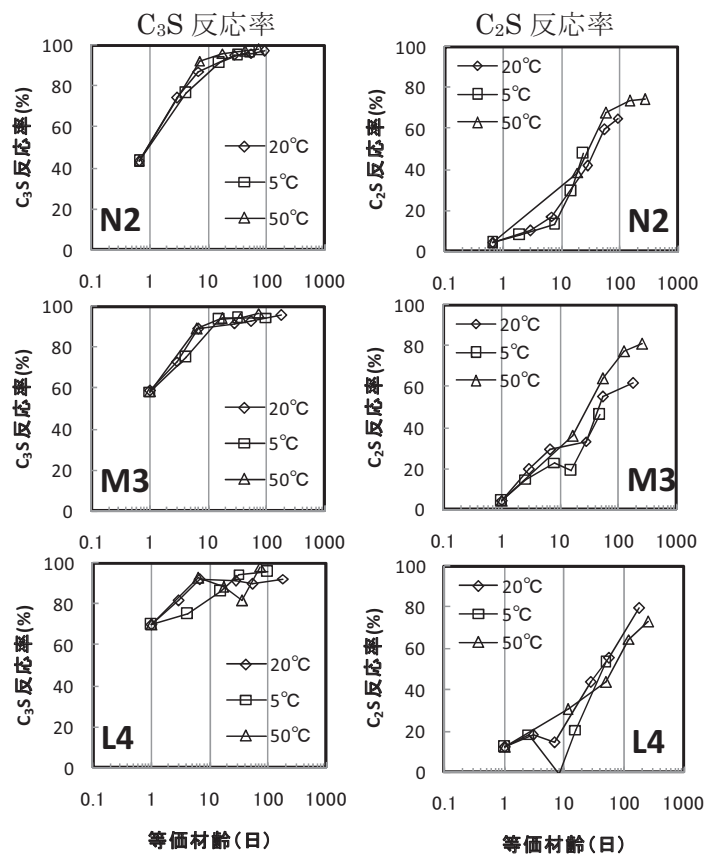

\begin{tabular}{|c|c|c|c|}
\hline セメント種類 & 記号 & $\begin{array}{c}\text { 養生温度 } \\
\left({ }^{\circ} \mathrm{C}\right)\end{array}$ & $\begin{array}{c}\text { 試験材齢 } \\
\text { (日) }\end{array}$ \\
\hline 早強ポルトランドセメント & $\mathrm{H}$ & $4 x^{2}$ & $7,14,56,119,182$ \\
\hline 普通ポルトランドセメント & $\begin{array}{l}\text { N1 } \\
\text { N2 }\end{array}$ & & \multirow[b]{2}{*}{$1,3,7,28,56$} \\
\hline 中康熱ポルトランドヤメント & $\begin{array}{l}\text { M1 } \\
\text { M2 }\end{array}$ & 20 & \\
\hline & $\begin{array}{l}\text { M3 } \\
\text { M4 }\end{array}$ & 35 & $2,3,14,35$ \\
\hline 低熱ポルトランドセメント & $\begin{array}{l}\text { L1 } \\
\text { L2 } \\
\text { L3 } \\
\text { L4 }\end{array}$ & 50 & $2,3,7,28$ \\
\hline
\end{tabular}

図 2 等価材齢と $\mathrm{C}_{3} \mathrm{~S}, \mathrm{C}_{2} \mathrm{~S}$ 反応率の関係

表 3 実験計画

および $50^{\circ} \mathrm{C}$ で所定の材齢まで水中養生し，JISR5201-1997 に準じ て圧縮強度を測定した。試験材齢は表 3 に示寸通りとした。

中心部分に $\mathrm{TC}$ 熱電対を埋め込んだ試験体を用意し，打設直後か ら 10 分間隔で温度を測定しデータロガーに記録・管理した。

\section{2 モルタルの強度増進と温度依存性}

\section{2. 1 セメント種類と等価材齢}

図 3 に材齢と圧縮強度の関係を使用したセメントごとに示す.

早強セメント $(\mathrm{H})$ では, $35^{\circ} \mathrm{C}$ と $50^{\circ} \mathrm{C}$ で強度の発現が早く, $5{ }^{\circ} \mathrm{C}$ で 若干遅いが温度依存性は小さい, 普通セメント $(\mathrm{N})$ では, 温度依存性 が認められ, $5^{\circ} \mathrm{C}$ で遅延し, $35^{\circ} \mathrm{C}$ と $50^{\circ} \mathrm{C}$ で促進する傾向が示された. 中庸熱セメント $(\mathrm{M})$ では, 普通セメントよりも温度依存性が大きく, 低熱セメント(L)では，さらに顕著な温度依存性が示されている。

また，ほぼすべてのセメントの $50^{\circ} \mathrm{C} て ゙$ 養生した材齢 28 日の強度， $35^{\circ} \mathrm{C}$ で養生した材齢 35 日の強度が $20^{\circ} \mathrm{C}$ で養生した材齢 56 日の強 度を下回る結果となった。初期材齢の養生温度が長期強度に影響を 与えることはよく知られている。杉山らによれば，普通セメントは 0.5 日まで ${ }^{15)}$, 中庸熱セメントでは $1 \sim 3$ 日 16), 早強セメントでは 3 時間まで，低熱セメントでは 0.5 日まで ${ }^{17) の}$ 間に履歴する温度が長 期強度に影響を与えるとされている。この結果をふまえ, 本研究で は, 1 日間 $20^{\circ} \mathrm{C}$ 養生した後, それぞれの養生温度での養生を行うこ 

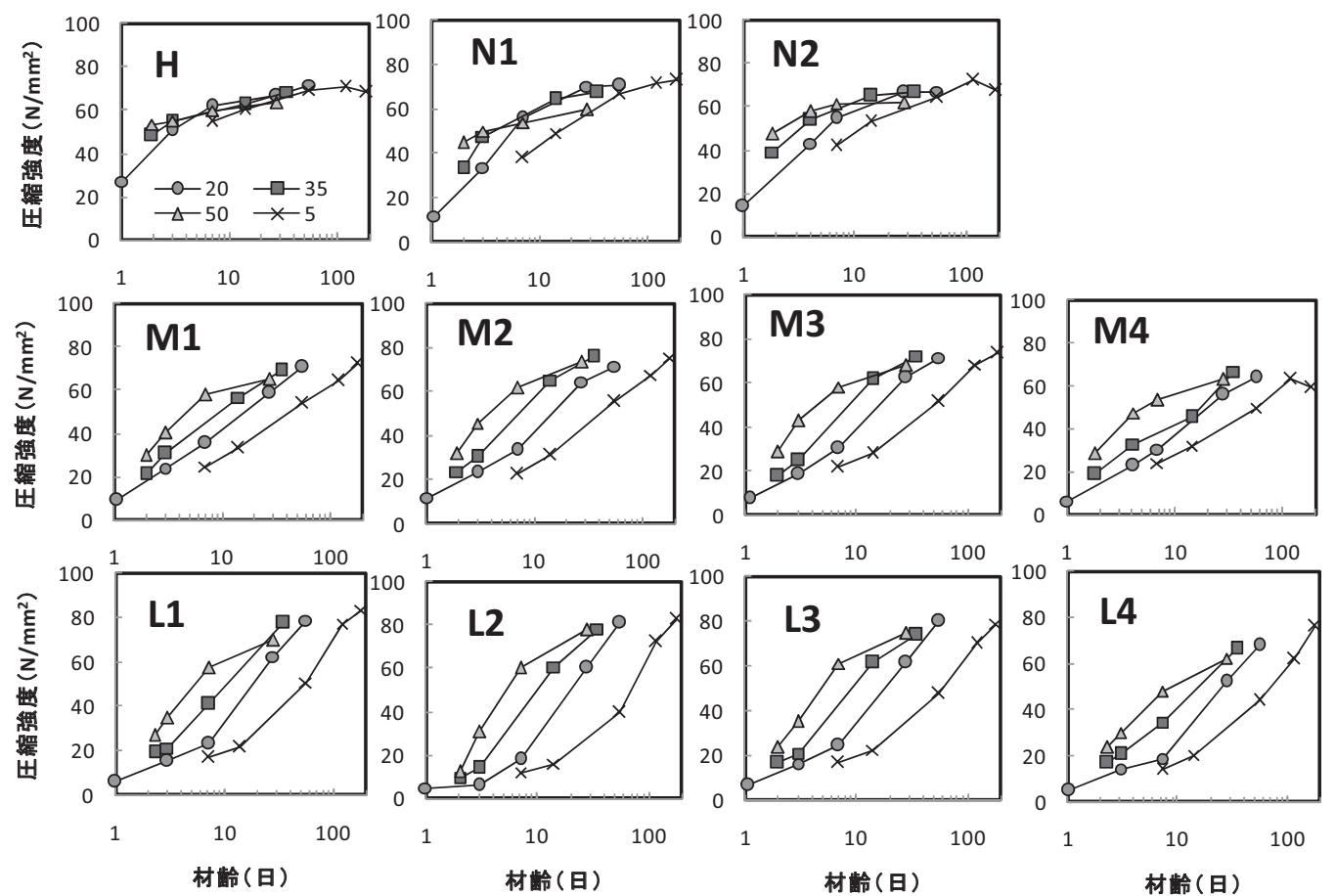

図 3 材齢とモルタル圧縮強度の関係

とでその影響が低減されると推測した。しかしながら，初期高温の 影響が認められると結果となった。この理由は本研究の範囲では明 確ではない.

以上の結果を用い, 温度依存性を表す見かけの活性化エネルギー を求める.

$20^{\circ} \mathrm{C}$ 標準養生のもので, 材齢と強度の関係を以下に示すゴンペル ツ曲線で近似し, 曲線形状を決定する係数 $a, b$ を非線形最小二乗法 により決定する.

$$
F(t)=F_{\text {inf }} \cdot \exp \left(a \cdot T_{e}^{b}\right)
$$

ここに, $F_{\text {inf }}$ : 最終到達強度 $\left(\mathrm{N} / \mathrm{mm}^{2}\right)$,

$$
\begin{aligned}
& T_{e}: \text { (等価) 材齢, } \\
& a, b: \text { 実験定数 }
\end{aligned}
$$

また，ゴンペルツ曲線の係数 $\mathrm{a}, \mathrm{b}$ について, $\mathrm{b}$ はセメント種類に よらずほぼ一定の值となったため, ここでは一定とし, 使用したセ

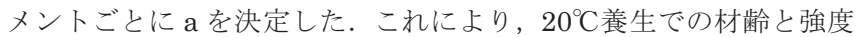
増進の関係がそれぞれのモルタルについて得られた事となる. 次に, 他の養生温度での材齢を式(2)(3)により等価材齢に換算し, 各等価材 齢での圧縮強度の実験值が $20^{\circ} \mathrm{C}$ 養生での材齢々強度の関係に一致 するよう，それぞれのモルタルごとに見かけの活性化エネルギーの 值を最小二乗法により求めた。これをそれぞれのセメントで得られ る見かけの活性化エネルギー $E$ とした。 ただし， $35^{\circ} \mathrm{C}, 50^{\circ} \mathrm{C}$ 養生で は材齢 28 日以降の強度停滞が認められており，ここで検討寸る温 度依存性以外の影響と考えられるため, 材齢 14 日までの実験結果 を用いることとした。

それぞれのセメントで得られた見かけの活性化エネルギー $\mathrm{E}$ ，等 価材齢を用いて式(4)により計算した圧縮強度（以下, 計算強度とす る）と実測強度の平均自乗平方誤差（RMS）および相関係数，ゴン

\begin{tabular}{|c|c|c|c|c|c|}
\hline \multirow{2}{*}{$\begin{array}{c}\text { セメント } \\
\text { 種類 }\end{array}$} & \multirow{2}{*}{$\frac{E}{(\mathrm{~J} / \mathrm{mol})}$} & \multirow{2}{*}{$\begin{array}{c}\text { RMS } \\
\left(\mathrm{N} / \mathrm{mm}^{2}\right)\end{array}$} & \multirow{2}{*}{ 相関係数 } & \multicolumn{2}{|c|}{ ゴンペルツ曲線係数 } \\
\hline & & & & a & b \\
\hline $\mathrm{H}$ & 33121 & 0.91 & 0.929 & -0.92 & \multirow{11}{*}{-0.54} \\
\hline $\mathrm{N} 1$ & 39344 & 1.72 & 0.955 & -1.82 & \\
\hline N2 & 37555 & 0.92 & 0.981 & -1.51 & \\
\hline M1 & 38198 & 0.52 & 0.996 & -2.51 & \\
\hline M2 & 43513 & 1.02 & 0.996 & -2.68 & \\
\hline M3 & 43330 & 1.12 & 0.995 & -3.26 & \\
\hline M4 & 39009 & 1.36 & 0.976 & -2.95 & \\
\hline L1 & 47515 & 1.71 & 0.970 & -4.48 & \\
\hline $\mathrm{L} 2$ & 46780 & 1.73 & 0.987 & -6.03 & \\
\hline L3 & 43823 & 1.05 & 0.994 & -4.30 & \\
\hline $\mathrm{L} 4$ & 42900 & 1.06 & 0.982 & -4.59 & \\
\hline
\end{tabular}
ペルツ曲線の係数 $a, b$ を表 4 に示す.

図 4 に実測強度と計算強度をセメント種別ごとに示す，計算強度
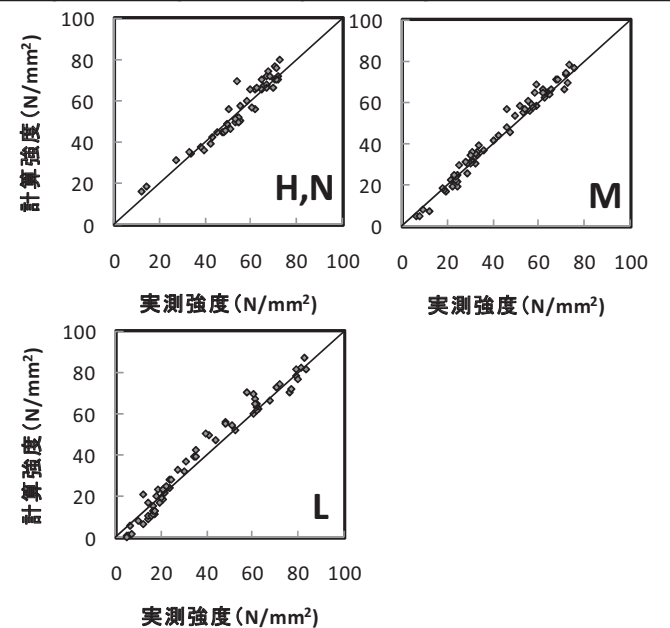

実測強度 $\left(\mathrm{N} / \mathrm{mm}^{2}\right)$

図 4 実測強度と計算強度の関係

表 5 鉱物割合の相関行列および鉱物割合と活性化エネルギー の相関係数

\begin{tabular}{|c|c|c|c|c|r|}
\hline & $\mathrm{C}_{3} \mathrm{~S}$ & $\mathrm{C}_{2} \mathrm{~S}$ & $\mathrm{C}_{3} \mathrm{~A}$ & $\mathrm{C}_{4} \mathrm{AF}$ & \multicolumn{1}{c|}{$\mathrm{Ea}$} \\
\hline $\mathrm{C}_{3} \mathrm{~S}$ & 1 & -0.999 & 0.640 & 0.233 & -0.938 \\
\hline $\mathrm{C}_{2} \mathrm{~S}$ & -0.999 & 1 & -0.646 & -0.225 & 0.942 \\
\hline $\mathrm{C}_{3} \mathrm{~A}$ & 0.640 & -0.646 & 1 & -0.519 & -0.632 \\
\hline $\mathrm{C}_{4} \mathrm{AF}$ & 0.233 & -0.225 & -0.519 & 1 & -0.221 \\
\hline
\end{tabular}



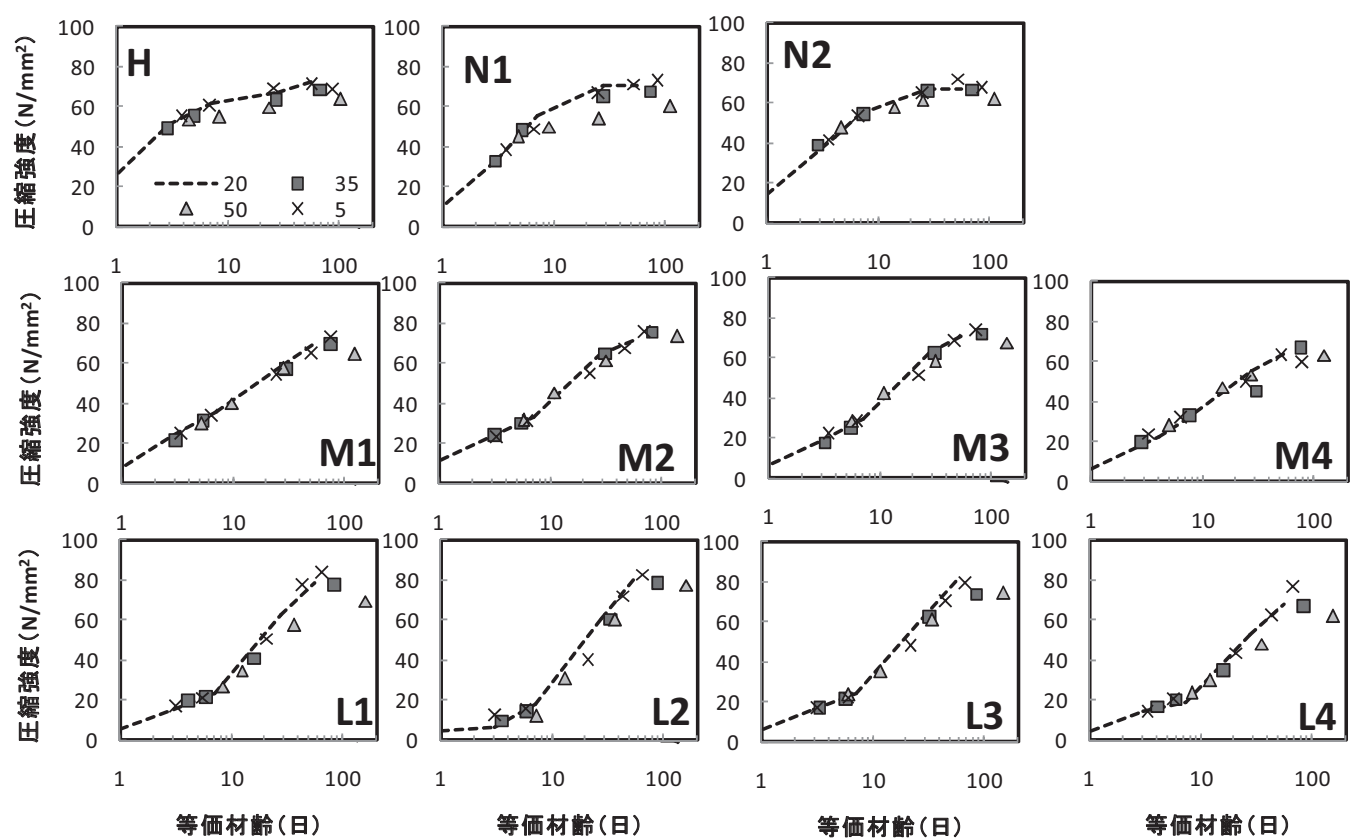

図 5 等価材齢と圧縮強度の関係

は実測強度と良い対応を示した。これにより，得られた見かけの活 性化エネルギーおよび材齢と強度の関係式は実験結果を良く表すも のと判断し, 以降の検討を行うこととした。

鉱物組成が見かけの活性化エネルギーの值に及ぼす影響を検討す るため, 鉱物それぞれの割合を説明変数とした回帰分析を行った。 説明変数間の交互作用を検討寸るため, 表 5 に説明変数間の相関係 数を示す. あわせて各鉱物割合と見かけの活性化エネルギーの相関 係数を示すそそれぞれの鉱物割合と活性化エネルギーの相関を見る と, $\mathrm{C}_{3} \mathrm{~S}, \mathrm{C}_{2} \mathrm{~S}$ 割合との相関係数は 0.9 以上と高く, $\mathrm{C}_{4} \mathrm{AF}$ 割合は相 関係数 0.221 とほとんど相関が認められなかった. 説明変数間の相 関をみると $\mathrm{C}_{3} \mathrm{~S}$ と $\mathrm{C}_{2} \mathrm{~S}$ 割合は相関が高く, 交互作用となる。よっ て, $\mathrm{C}_{2} \mathrm{~S}$ 割合と $\mathrm{C}_{3} \mathrm{~A}$ 割合をそれぞれ説明変数として重回帰分析を行 った。その結果， $\mathrm{C}_{2} \mathrm{~S}$ 割合は $1 \%$ 有意となるが， $\mathrm{C}_{3} \mathrm{~A}$ 割合は $5 \%$ 有意 にもならなかった，見かけの活性化エネルギーの值は $\mathrm{C}_{2} \mathrm{~S}$ 割合のみ で表され，回帰式は以下の通りとなる.

$$
E=206.9 \times C_{2} S+34091.1
$$

$$
\text { ここに, } C_{2} S: \text { セメント中の } C_{2} S \text { 割合 }(\%)
$$

図 5 に式(5)により計算された見かけの活性化エネルギーを用い て算定した等価材齢と圧縮強度の関係を示寸. 図中の点線は $20^{\circ} \mathrm{C} の$ 結果である．全てのセメントで等価材齢 28 日程度までの異なる養 生温度の強度増進をほぼ一義的に表すことができた。

\subsection{2 セメント種類と強度増進曲線形状}

セメント種類による強度増進曲線形状の相違を検討するため, 4.2.1 で求めたゴンペルツ曲線の係数 a と鉱物組成の関係を鉱物そ れぞれの割合を説明变数とした回帰分析を行った. 表 6 に係数 a 鉱物それぞれとの相関係数を示す． $\mathrm{C}_{3} \mathrm{~S}$ 割合との相関が最も高く, $\mathrm{C}_{3} \mathrm{~A}$ も若干の相関が認められた. $\mathrm{C}_{3} \mathrm{~S}, \mathrm{C}_{3} \mathrm{~A}$ 割合を説明変数として 重回帰分析を行った結果, $\mathrm{C}_{3} \mathrm{~S}$ 割合のみが $1 \%$ 有意となった.

図 6 に $\mathrm{C}_{3} \mathrm{~S}$ 割合および $\mathrm{C}_{3} \mathrm{~S}$ 割合の逆数と係数 $\mathrm{a}$ の関係を示す. $\mathrm{C}_{3} \mathrm{~S}$ 割合の逆数と係数 $\mathrm{a} の$ 相関係数は -0.956 , 重相関係数 0.910 と なり, 係数 a は以下の回帰式で表されるとした.

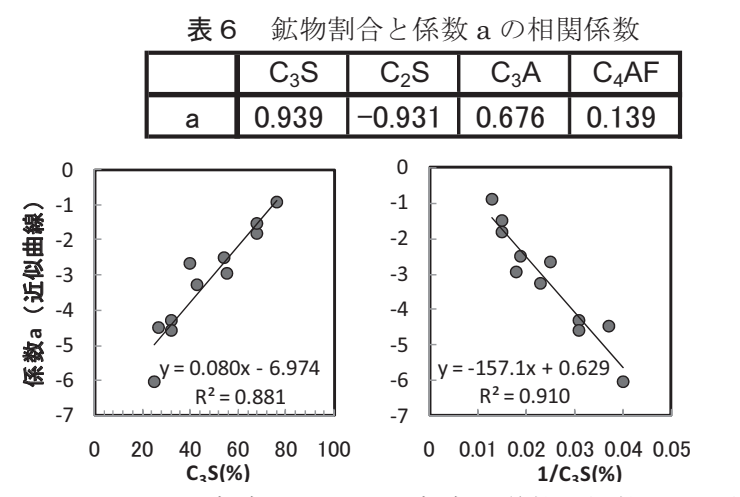

図 $6 \quad \mathrm{C}_{3} \mathrm{~S}$ 割合および $\mathrm{C}_{3} \mathrm{~S}$ 割合の逆数と係数 $\mathrm{a}$ の関係

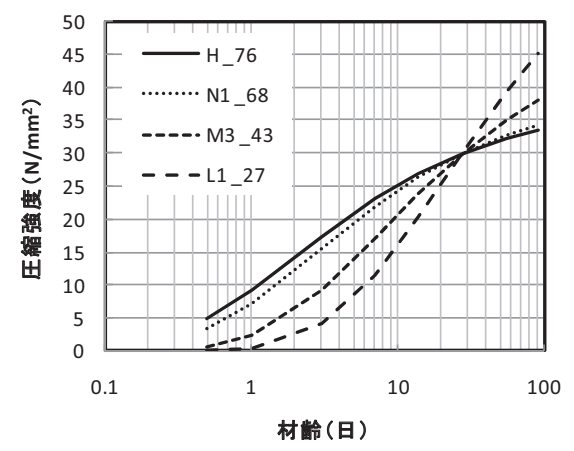

図 7 強度増進曲線形状の比較

$a=-157.1 / C_{3} S+0.629$

ここに, $C_{3} S:$ セメント中の $C_{3} S$ 割合 $(\%)$

図 7 に a は式(4)による值， b は-0.54一定として，H， N1，M3， L1 のそれぞれの強度増進曲線を示す. $20^{\circ} \mathrm{C} 28$ 日強度を $30 \mathrm{~N} / \mathrm{mm}^{2}$ として算出した。 凡例に $\mathrm{C}_{3} \mathrm{~S}$ 割合を示した。 $\mathrm{C}_{3} \mathrm{~S}$ 割合の多い早強セ メントほど強度の立ち上がりが早く, 図 4 に示したセメント種類に よる強度増進の傾向を良く表していた。 


\section{5. まとめ}

本研究の結果は以下に要約される.

1)セメントペーストの実験から， $\mathrm{C}_{2} \mathrm{~S}$ の反応の温度時間依存性は積 算温度で表せないことを示した。これにより， $\mathrm{C}_{2} \mathrm{~S}$ 割合が多い低熱 セメントのコンクリート強度増進の温度時間依存性を積算温度で表 せないことが説明できた。

2)各種セメントを用いたモルタルの実験から，強度増進の温度時間 依存性は等価材齢で表すことができ，その時の見かけの活性化エネ ルギーはセメントの $\mathrm{C}_{2} \mathrm{~S}$ 割合から算定できることを示した.

3)材齢と強度増進の関係を表す強度増進曲線の形状は，セメント種 類により異なり，ゴンペルツ曲線を近似した時には曲線形状を決定 寸る係数を $\mathrm{C}_{3} \mathrm{~S}$ 割合から算出することが出来た.

\section{謝辞}

本実験の実施にあたり，日鐵セメント株式会社，太平洋セメント 株式会社, 宇部三菱セメント株式会社および株式会社フローリック より材料の提供・実験に関し多大なご協力を頂きました。ここに記 して謝意を示します.

\section{参考文献}

1) 寒中コンクリート工事施工指針・同解説，日本建築学会，2010

2) 洪 悦郎, 長島 弘, 鎌田 英治: 寒中コンクリート, 技術書院, 2000

3) 田中敏嗣, 丸岡正知, 竹内良, 富田六郎：ビーライトセメントを用いた 高強度コンクリートの強度発現に及ぼす温度履歴の影響, コンクリート工 学年次論文集, Vol.18, No.1, pp. 237-242, 1996

4) 小山宣幸, 平田久則, 上田厚元, 小島利広 : 低熱ポルトランドセメント を用いたコンクリートの積算温度に関する一考察, コンクリート工学年次 論文報告集，vol.19, pp.523-528, 1997

5) 因幡芳樹, 長田浩治, 洪杰, 嵩英雄 : 各種セメントを用いたコンクリー トの強度発現に及ぼす養生温度の影響, コンクリート工学年次論文集, No.22, Vol.2, pp.475-480, 2000

6）谷口円，桂修，松村宇，吉野利幸：各種セメントを使用したコンクリー トの圧縮強度增進性状, コンクリート工学年次論文集, Vol. 30, No.1, pp. 357-362, 2008

7) "Standard Practice for Estimating Concrete Strength by the Maturity Method", ASTM C 1074-98

8) Anton K. Schindler: Effect of Temperature on Hydration of Cementitious Materials, ACI Materials Journal, Vol. 101, No. 9, pp.72-81, Jan.-Feb. 2004

9) 吉野亮悦, 住田守 : Rietveld 法によるセメント鉱物の定量, セメント・ コンクリート論文集 No.53，pp.84-89，1999

10) 佐川孝広，桂修，関口岳彦，若杉伸一：セメント鉱物の反応率に及ぼす 水セメント比と養生条件の影響, セメントコンクリート論文集, Vol.58, pp.23-30, 2004

11) 星野清一, 平尾宙, 山田一夫 : $X$ 線回折/リートベルト法によるセメント ペーストの水和反応の定量解析，コンクリート工学年次論文集，Vol.28， No. 1, pp.41-46, 2006

12）松下哲郎，平尾宙，丸山一平，野口貴文：リートベルト法によるセメン 卜の水和反応の定量解析, 日本建築学会構造系論文集, No.73, Vol.623, pp.1-8, 2008.1

13) Izumi, F. and Ikeda, T. : "A Rietveld-analysis program RIETAN-98 and its application to Zeolites,” Mater. Sci. Forum, Vols. 321-324, pp.198-203, 2000

14）佐川孝広 : ポルトランドセメントの水和反応モデルによる強度推定, 日 本建築学会大会学術講演梗概集 A-1, pp.467-468, 2009

15）杉山央，栘田佳寛 : 初期高温履歴を受けたコンクリートの長期強度発現 性，日本建築学会構造系論文集，第 515 号，pp. 23-30，1999.1

16) 杉山央, 地濃茂雄 : コンクリートの強度発現に及ぼす初期高温履歷の影 響に関する定量的検討-中庸熱ポルトランドセメントを用いたモルタルに よる基礎実験-：日本建築学会構造系論文集，No. 525, pp.7-13,1999.11
17）杉山央, 栘田佳寛 : 早強および低熱ポルトランドセメントを用いたコン クリートの強度発現に及ぼす初期高温履歷の影響, 日本建築学会構造系論 文集，No. 520，pp.9-16, 1999.7

(2010年 8 月 6 日原稿受理，2010年11月29日採用決定） 